\title{
"Siliconomas" mamarios por inyección de silicona líquida
}

\author{
Breast siliconomas resulting from the injection of liquid silicone
}

Jheferson Contreras-Grande ${ }^{1,2, a}$, Dayana Pastor-Gutiérrez ${ }^{1, b}$, Guillermo Salvatierra ${ }^{1, b}$
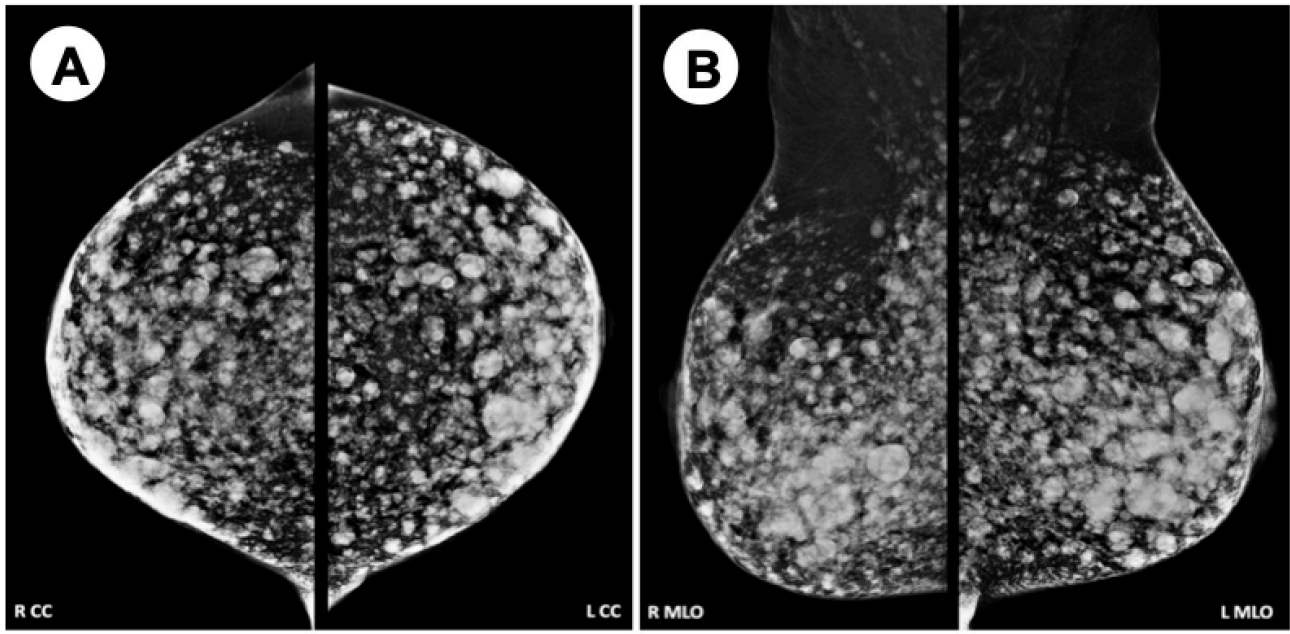

Mujer de 65 años, sin antecedentes de importancia, fue referida por dolor mamario; al examen físico se encontró mamas de consistencia dura. La mamografía mostró múltiples imágenes nodulares redondeadas de alta densidad de distribución dispersa y generalizada en ambas mamas. En la ecografía se evidenció artefacto en "tormenta de nieve" en ambas mamas. La paciente mencionó posteriormente el antecedente de inyección de silicona líquida en las mamas hace 20 años. Los "siliconomas" aparecen como consecuencia de reacciones granulomatosas a la silicona ya sea por la rotura de implantes o por inyección directa de silicona como en este caso. Recomendamos en estos casos, realizar resonancia magnética, como parte del tamizaje anual, por ser el único método técnicamente, que detectaría un carcinoma infiltrante o in situ de grado intermedio y alto.

A previously healthy 65 -year-old woman was referred due to breast pain, the physical examination revealed that both breasts were hard on palpation. Mammography revealed multiplate and scattered rounded nodular lesions in both breasts. The ultrasound revealed a snow pattern in both breasts. The patient later recalled to have received an injection of liquid silicone 20 years ago. Siliconomas are the result of a granulomatous reaction to silicone, either due to leakage of implants or due to direct injection. We recommend that in these patients magnetic resonance images should be obtained every year to rule out carcinoma in-situ. 